ステップスリットケーソンの実用化に向けた一検討（第 1 報） Study on the application of a Step-Shaped Slit Caisson for practical use -about the reflection coefficient-

\author{
安 成 模” ・藤原 隆一“ - 倉田 克彦“・角野 昇八“” \\ Sung Mo.AHN， Ryuichi.FUJIWARA， Katsuhiko.KURATA， Shohachi.KAKUNO
}

\begin{abstract}
A new type of breakwater with a step-shaped slit caisson has been developed and some very fascinating results have been found.It was found that this breakwater has low reflection in a wider range of wave frequency compared to conventional slit-type breakwaters.A numerical analysis which combines the method of matched asymptotic expansions with a boundary element method has been applied for calculation of the reflection coefficients for these structures. However the previous studies were on the condition of non rubble mound. The present paper focuses on the reflection coefficients of the step-shaped slit caisson on the rubble mound in order to apply the step-shaped slit caisson for practical use.
\end{abstract}

Keywords:step-shaped slit caisson, conventional slit-type breakwater, rubble mound, reflection coefficient

1.はじめに

近年, 海域制御構造物は大水深に設置されることが多くなり, 波高が大きく周期が長い波に対しても消波効果 を持つ低反射構造物の必要性が高まっている. 筆者らは, 波の周期に依存せず, 広い周期帯にわたる低反射機能 を持つ大水深波浪制御構造物の研究に取り組み, 特定の周期だけでなく広い周期帯の波に対して優れた消波効果 を発揮する消波構造物の開発を進めてきた. そして, 直立消波工の消波メカニズムおよび波動論の知識に基つき, 従来より広い周期帯において低反射機能を有する新しい直立消波工の形式を提案した.この新たに提案したステッ プスリットケーソンの消波特性については実験ならびに数値解析によって既に検討を行ってきたが,これまでの 研究はマウンドのない場合であった. 本研究では, マウンド上でのステップスリットケーソンの張出部, 嵩上げ 部が反射率に及ぼす影響を水理模型実験によって検討するとともに, マウンドのある場合の理論を新たに構築し て検証する. また，消波効果か高いステップスリットケーソンの形状・寸法についても検討を加えた.

\title{
2. 理論解析
}

解析領域としては，図ー1に示すような傾斜マウン ド上に設置されている綎スリット壁式消波工の鉛直 2 次元断面を考える. $\mathrm{x}$ 軸を自由表面上に岸向きにとり， y 軸を自由表面より上向きにとる. 流体領域 $(\Omega)$ で は非粘性・非回転運動を仮定し, 微小振幅波を対象 とする.このような流体領域では, 時間項 $\exp (-i \sigma)$ を除いた速度ポテンシャル $\phi(x, y)$ は，以下に示す支配 方程式と境界条件を満足せねばならない。

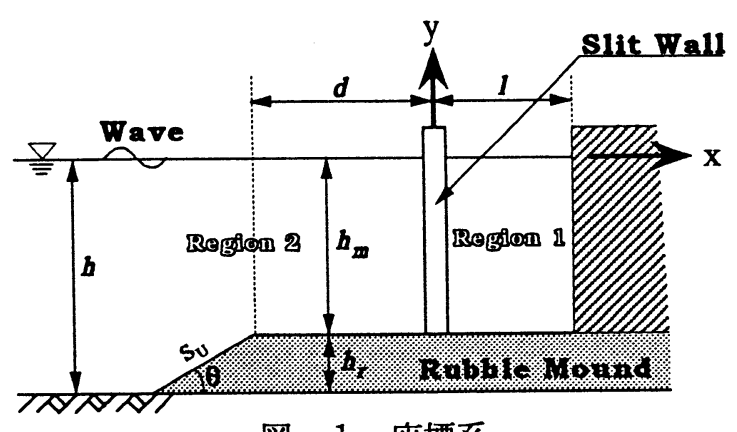

図-1 座標系

$$
\begin{array}{ll}
\nabla^{2} \phi=0 & \text {; in } \Omega \\
\partial \phi / \partial y-v \phi=0 & \text {; on } y=0 \\
\partial \phi / \partial y=0 & \text {; on } y=-h \\
\partial \phi / \partial n=0 & \text {; on } \mathrm{S}_{\mathrm{U}} \\
\partial \phi / \partial x=0 & \text {; on } x=l \\
\lim _{\mathrm{l} \rightarrow \infty}\left(\partial \phi_{x} / \partial|x|-i k \phi_{x}\right)=0 &
\end{array}
$$

ここで, $\sigma=2 \pi / T$ ( $T$ は波の周期), $i$ : 虚数単位, $v=\sigma^{2} / g, g:$ 重力加速度, $n:$ 流体領域より外向き法線, $k:$ 波数 ( $v=k \tanh h$ を満足する実正根), $\mathrm{S}_{\mathrm{v}}$ : 任意海底地形上の不透過面, $l$ : スリット壁中心より背後の不透過壁面まで の距離, $\phi_{x}$ : 散乱波の速度ポテンシャルである. また, 水深を $h$, マウンド上の水深を $h_{m}$, スリット壁からマウ ンド天端の沖端までの距離を $d$ とし, マウンドの傾斜部は $\mathrm{x}$ 軸となす角度が $\theta$ で一定, 天端は $\mathrm{x}$ 軸と平行である

\begin{tabular}{lll}
\hline 正会員 & 東洋建設 (株) & 鳴尾研究所（广 663 西宮市鳴尾兵三丁目十七番六号） \\
.... フェロー会員 & 東洋建設 (株) 鳴尾研究所 \\
正会員 & 大阪市立大学土木工学科助教授
\end{tabular}


とする.

式 (6) の放射条件は，ここで対象としている現象では， $\rho$ を複素係数の反射率として以下のようにおくことが できる. $\quad \phi(x, y) \rightarrow\left(e^{i k x}+\rho e^{-i k x}\right) \frac{\cosh k(y+h)}{\cosh k h} \quad(x \rightarrow-\infty)$

ここで全流体領域をスリット壁を境界として沖側と岸側に分け, 岸側を領域 1 , 沖側を領域 2 とする. 両領域 にグリーンの定理を適用すれば以下の式を得る.

$$
\begin{aligned}
\phi_{1}(\xi, \eta)=\int_{-h_{m}}^{0}\left[\frac{\partial \phi_{1}}{\partial x}\left(0_{+}, y\right) G_{1}\left(0_{+}, y ; \xi, \eta\right)-\phi_{1}\left(0_{+}, y\right) \frac{\partial G_{1}}{\partial x}\left(0_{+}, y ; \xi, \eta\right)\right] d y+\int_{-h_{m}}^{0} \phi_{1}(l, y) \frac{\partial G_{1}}{\partial x}(l, y ; \xi, \eta) d y \\
\phi_{2}(\xi, \eta)=\phi_{0}(\xi, \eta)+\int_{-h_{m}}^{0}\left[\phi_{2}\left(0_{-}, y\right) \frac{\partial G_{2}}{\partial x}\left(0_{-}, y ; \xi, \eta\right)-\frac{\partial \phi_{2}}{\partial x}\left(0_{-}, y\right) G_{2}\left(0_{-}, y ; \xi, \eta\right)\right] d y \\
+\quad \int_{-d}^{0} \phi_{2}\left(x,-h_{m}\right) \frac{\partial G_{2}}{\partial y}\left(x,-h_{m} ; \xi, \eta\right) d x+\int_{\Gamma} \phi_{2}(x, y) \frac{\partial G_{2}}{\partial \eta}(x, y ; \xi, \eta) d s
\end{aligned}
$$

ここに, $G$ はグリーン関数であり, $(\xi, \eta)$ はそれぞれの領域内の任意点の座標, $(x, y)$ は各積分経路上の座標である. また, $\phi_{2}\left(x,-h_{m}\right)$ は水平天端上の速度ポテンシャル, 「はマウンド法面部のみの積分経路を表し, $\phi_{2}(x, y)$ は $\Gamma$ 上速 度ポテンシャルである.

また，スリット部の影響を表す項として，例えば角野ら（1989）における取扱と同じく，スリット近傍に対し ては柱体列を過ぎる流れを表す以下のような内部解を与える.

$$
\phi(\xi, \eta)=(\xi \pm C(\eta)) U(\eta)+C_{0}^{\prime}(\eta)
$$

ここで, 正負符号はそれぞれ領域 $1 ， 2$ に対応し， $U(\eta)$ は一様流部での流速， $C_{0}^{\prime}(\eta)$ は任意定数である. また, $C(\eta)$ は” blockage coefficient” と呼ばれ, 柱体とスリットの平面断面から一義的に決定されるような理論実定数で, 単 純な断面に対しては既知量である.

以上のようにして求めた外部解と内部解を接合するために, 式 (8) において $\xi \rightarrow+0$ の極限形を求めると次式 を得る.

$$
\phi_{1}\left(0_{+}, \eta\right)=2 \int_{-h_{m}}^{0} \frac{\partial \phi_{1}}{\partial x}\left(0_{+}, y\right) G_{1}\left(0_{+}, Y ; 0_{+}, \eta\right) d y+2 \int_{-h_{m}}^{0} \phi_{1}(l, y) \frac{\partial G_{1}}{\partial x}\left(l, y ; 0_{+}, \eta\right) d y
$$

同様の操作で，領域 2 に対する式（9）からは次式を得る.

$$
\begin{aligned}
\phi_{2}\left(0_{-}, \eta\right)= & 2 \phi_{0}\left(0_{-}, \eta\right)-2 \int_{-h_{m}}^{0} \frac{\partial \phi^{2}}{\partial x}\left(0_{-}, y\right) G_{2}\left(0_{-}, y ; 0_{-}, \eta\right) d y \\
& +2 \int_{-d}^{0} \phi_{2}\left(x_{1},-h_{m}\right) \frac{\partial G_{2}}{\partial y}\left(x,-h_{m} ; 0_{-}, \eta\right) d x+2 \int_{\Gamma} \phi_{2}(x, y) \frac{\partial G_{2}}{\partial n}\left(x, y ; 0_{-}, \eta\right) d s
\end{aligned}
$$

したがって, 式 (11) と式 (12) から得られる外部解の速度ポテンシャル差と式 (10) から得られる内部解の速 度ポテンシャル差を等値して, 両領域の解の接合を行うと, 以下の関係式を得る.

$$
\begin{aligned}
C(\eta) U(\eta)+\phi_{0}\left(0_{-}, \eta\right)= & \int_{-h_{m}}^{0} U(y) \cdot\left[G_{1}\left(0_{,}, y ; 0_{+}, \eta\right)+G_{2}\left(0_{-}, y ; 0_{-}, \eta\right)\right] d y+\int_{-h_{m}}^{0} \phi_{1}(l, y) \frac{\partial G_{1}}{\partial x}\left(l, y ; 0_{+}, \eta\right) d s \\
& -\int_{-d}^{0} \phi_{2}\left(x,-h_{m}\right) \frac{\partial G_{2}}{\partial y}\left(x,-h_{m} ; 0_{-}, \eta\right) d x-\int_{\Gamma} \phi_{2}(x, y) \frac{\partial G_{2}}{\partial n}\left(x, y ; 0_{-}, \eta\right) d s
\end{aligned}
$$

上式では，マウンド表面上の速度ポテンシャルに加え，背後の不透過壁面上での速度ポテンシャルも未知量で ある. それらを求めるために, 背後の不透過壁面上の速度ポテンシャルに対しては, $\xi$ 背面不透過壁に漸近させ て次式を得る.

$$
\phi_{1}(l, \eta)=2 \int_{-h_{m}}^{0}\left[\frac{\partial \phi}{\partial x}\left(0_{+}, y\right) G_{1}\left(0_{+}, y ; l, \eta\right)-\phi_{1}\left(0_{+}, y\right) \frac{\partial G_{1}}{\partial x}\left(0_{+}, y ; l, \eta\right)\right] d y
$$

同様に, 天端水平面上の速度ポテンシャルおよびマウンド傾斜部での速度ポテンシャルに対しても極限操作によ り以下の式を得る. 


$$
\begin{aligned}
& \phi_{2}\left(\xi,-h_{m}\right)-\int_{-d}^{0} \phi_{2}\left(x,-h_{m}\right) \frac{\partial G_{2}}{\partial y}\left(x,-h_{m} ; \xi,-h_{m}\right) d x=\phi_{0}\left(\xi-h_{m}\right)+\phi_{0}\left(\xi-h_{m}\right) \\
& \quad+\int_{h_{m}}^{0}\left[\phi_{2}\left(0_{-}, y\right) \frac{\partial G_{2}}{\partial x}\left(0_{-}, y ; \xi,-h_{m}\right)-\frac{\partial \phi_{2}}{\partial x}\left(0_{-}, y\right) G_{2}\left(0_{-}, y ; \xi,-h_{m}\right)\right] d y+\int_{\Gamma} \phi_{2}(x, y) \frac{\partial G_{2}}{\partial n}\left(x, y ; \xi,-h_{m}\right) d s \\
& \phi_{2}(\xi, \eta)-\int_{\Gamma} \phi_{2}(x, y) \frac{\partial G_{2}}{\partial n}(x, y ; \xi, \eta) d s=\phi_{0}(\xi, \eta) \\
& \quad+\int_{-h_{m}}^{0}\left[\phi_{2}\left(0_{-}, y\right) \frac{\partial G_{2}}{\partial x}\left(0_{-}, y ; \xi, \eta\right)-\frac{\partial \phi_{2}}{\partial x}\left(0_{-}, y\right) G_{2}\left(0_{-}, y ; \xi, \eta\right)\right] d y+\int_{-d}^{0} \phi_{2}\left(x,-h_{m}\right) \frac{\partial G_{2}}{\partial y}\left(x,-h_{m} ; \xi, \eta\right) d x
\end{aligned}
$$

未知関数 $U(\eta), \phi_{1}(l, y), \phi_{2}\left(x,-h_{m}\right), \phi_{2}(x, y)$ が求められて解か確定すれば, 式 (8), (9) を算定し, さらにそれらの $\xi \rightarrow \pm \infty に お け る$ 極限値を式（7）と此較することにより複素係数の反射率を決定することができる.

\section{3. 水理模型実験}

実験に用いた水槽は長さ $40 \mathrm{~m}$, 高さ $2.0 \mathrm{~m}$, 幅 $1.0 \mathrm{~m}$ の 2 次元造波水路で，造波機より約 $30 \mathrm{~m}$ 離れ, 水路壁面が一部ガラス張りとなっ ている地点に模型（図一2参照）を設置した. 前述したようにステップスリットケーソン各 部分の影響を検討するために，2種類のマウ ンド上で, 張出部の高さと嵩上け部の高さを 各々 3 種類（マウンド上の水深の $0.4,0.6$, 0.8 倍) ずつ組み合わせて変化させた図一 3 に示す 8 種類の形式の模型に対して実験を 行った. 今回の実験では, スリット部の開

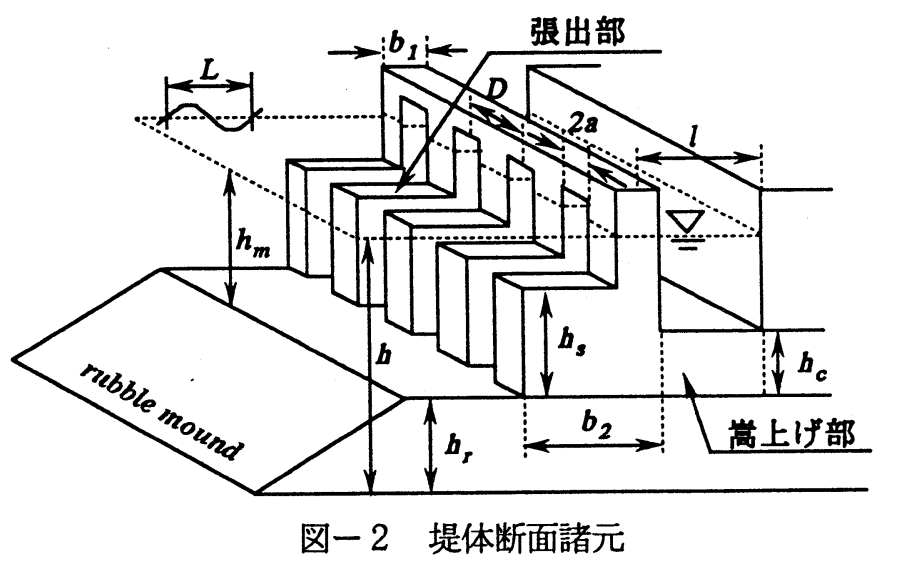
口率および遊水室幅は，それぞれ $2 a / D=0.33$, $l=16.6 \mathrm{~cm}$ で一定とした. また, 張出部の厚さは既往の研究（Fujiwara.ら，1994.) の結果に基づいてスリット壁の 厚さの 3 倍 $\left(b_{2} / b_{1}=3\right)$ とした. 水深は $50 \mathrm{~cm}$ で一定とし, 規則波を対象とした. 実験条件としては, 波の周期を $T=0.73 \mathrm{sec} \sim 2.19 \mathrm{sec}$ の範囲で 6 種類とし, 波形勾配が $H / L=0.01,0.02$ となるように波高を調節した. 反射率の測 定は，長さ $50 \mathrm{~cm}$ の容量式波高計 2 台を設置し，入・反射波の分離推定法（合田ら，1976.）により算定した.

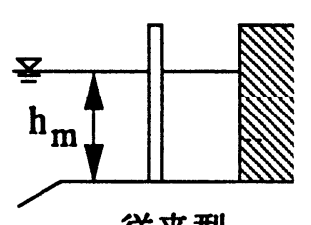

従来型

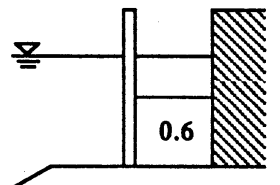

Type 2

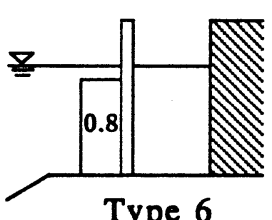

Type 6

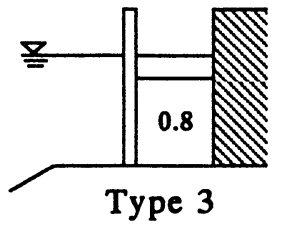

Type 3

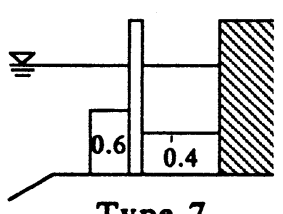

Type 7

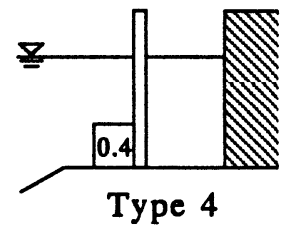

Type 4

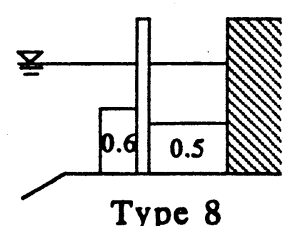

図一 3 模型断面

\section{4. 結果の考察}

1) 実験結果の考察

図ー4 (a), (b) は張出部の影響を示したもので, 遊水室内の嵩上げ部がない状態で張出部の高さをマウンド上 の水深 $\left(h_{m}\right)$ ) $0.4,0.6,0.8$ 倍之変化させた断面についての反射率を比較したものである. ここで, $h_{s} / h_{m}=0.0$ 場 合は従来型直立スリットケーソンに対応する. 図に示されるように, 張出部の高さ $\left(h_{s} / h_{m}\right)$ が大きくなるにつれて, 
反射率 $\left(K_{R}\right)$ が最小値を示す相対遊水室幅 $(l / L)_{p}$ より長周期側 (図の左側)では反射率の值が小さくなっている.一 方, 図一 5 (a), (b) は遊水室内の峬上げ部の高さ $\left(h_{c} / h_{m}\right)$ を変化させた断面についての反射率を示したものである. $h_{m} / h$ がほぼ0.6以下 (図一 5 (a)) では嵩上げ部の高さに応じて反射率の最小值が小さくなり, 既述の $(l / L)_{p}$ が長 周期側 (図の左側) にずれる傾向が見られる. しかしながら，嵩上げ部の高さをほぼ $h_{m} / h=0.8$ までげると(図一

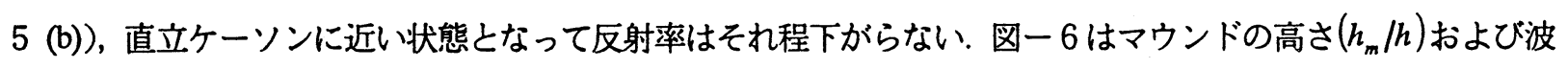
形勾配 $(H / L)$ の影響を示したもので，マウンドが高いほど，また，波形勾配が大きいほど反射率は低下する傾向 を示す. 以上の結果により，嵩上げ部は反射率を大きく低減させるが， $(l / L)_{p}$ が長周期側にずれて短周期側では反 射率が悪くなることが分かる. また, 張出部は反射率におよぼす影響が嵩上げ部よりは小さいが, その高さが高 くなると, 反射率がある程度低減することがわかる. さらに, マウンドがある場合の張出部, 嵩上げ部および $H / L$ による反射率の特性は，マウンドがない場合とほぼ同様であることか確認された．また，マウンドの高さの変化 は反射率に大きく影響する。

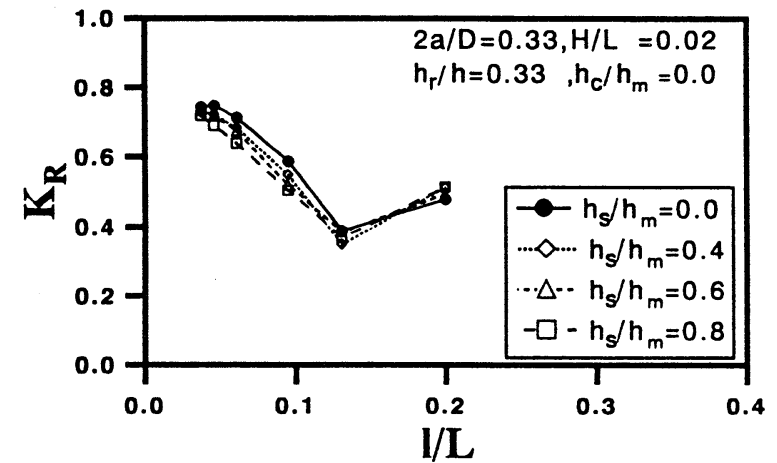

(a) $h_{r} / h=0.33$

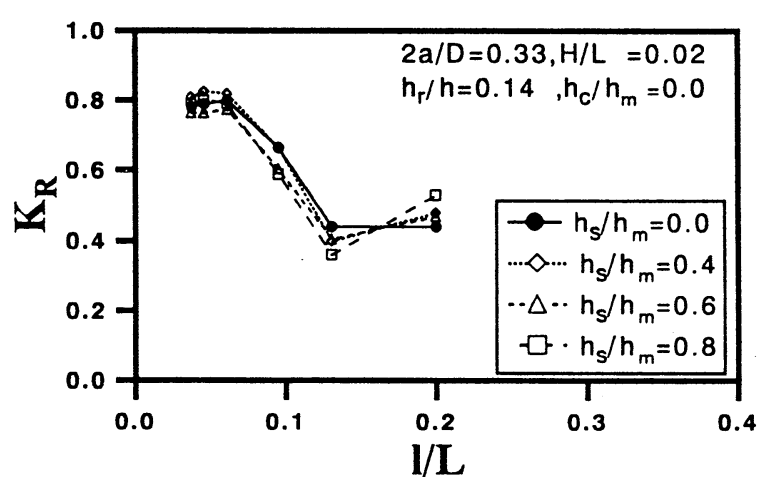

(b) $h_{r} / h=0.14$

図-4 実験結果（張出部の影響）

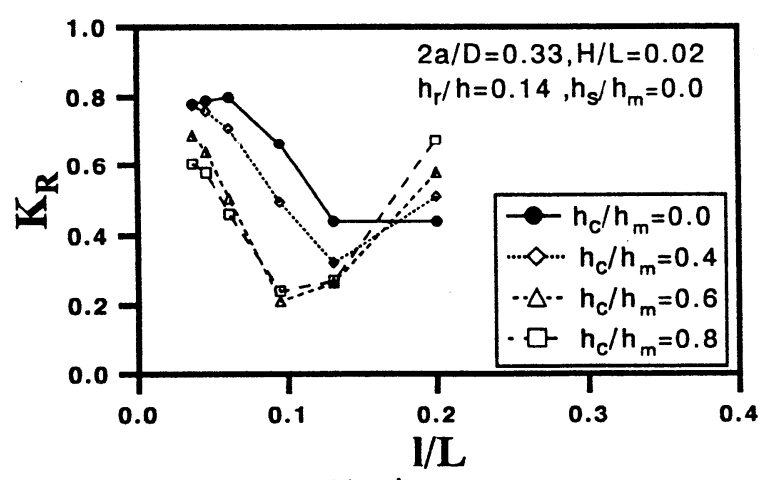

(a) $h_{r} / h=0.33$

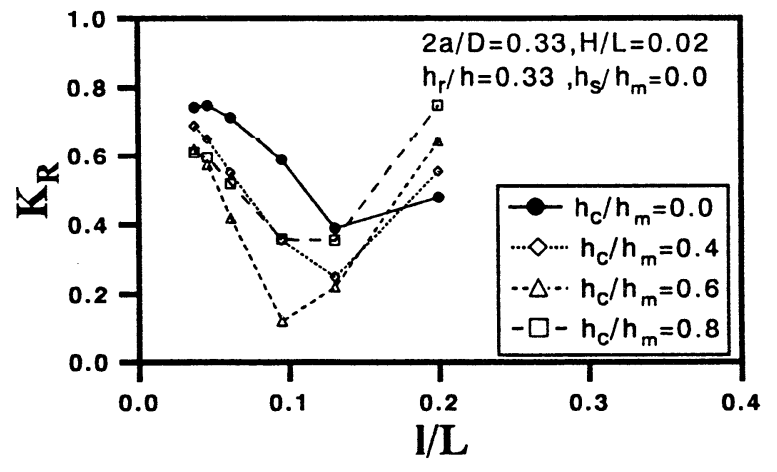

(b) $h_{r} / h=0.14$

図ー5 実験結果（嵩上け部の影響）

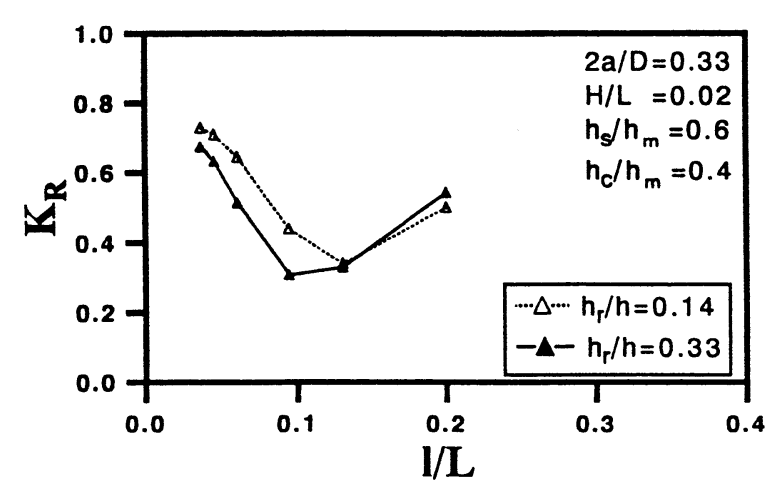

(a) $h_{r} / h$ の影響

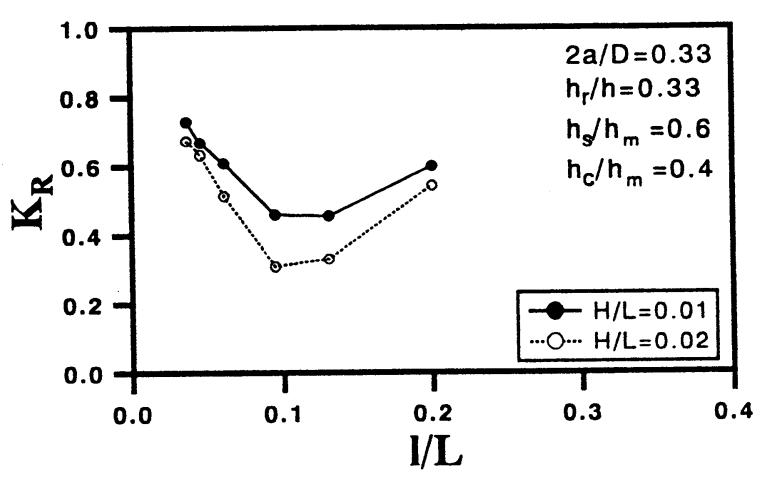

(b) $H / L$ の影響

図一6 実験結果（マウンドの高さおよび波形勾配の影響） 


\section{2 ) 理論の検証}

マウンドの影響を考慮しない本理論の基本的な妥当性はこれまでにも検証されているが, マウンド上に設置さ れた場合についての今回の理論の妥当性を検証するために理論値と実験值を比較した. その例を図一7 (a), (b) に示す. なお, スリット壁でのエネルギー損失の影響は, 既往の研究 (角野ら, 1989.) と同様, blockage coefficient を複素係数とすることで考慮した. 図より, 実験値と計算値は良好な一致を示していて, マウンドがある場合の 本理論の妥当性が得られたといえる.

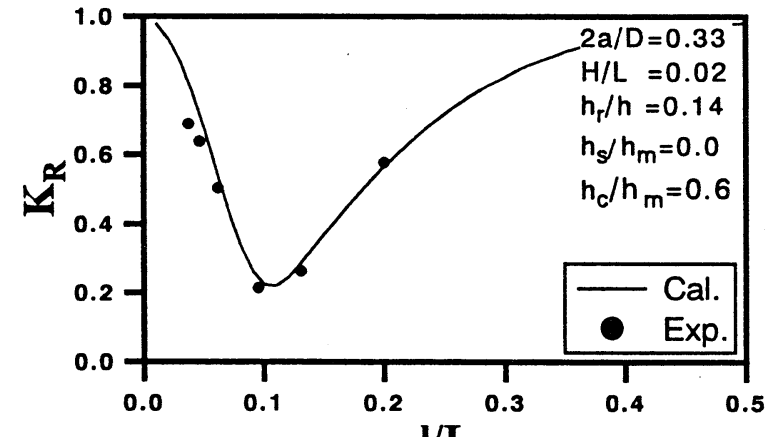

$\mathbf{1} / \mathbf{L}$

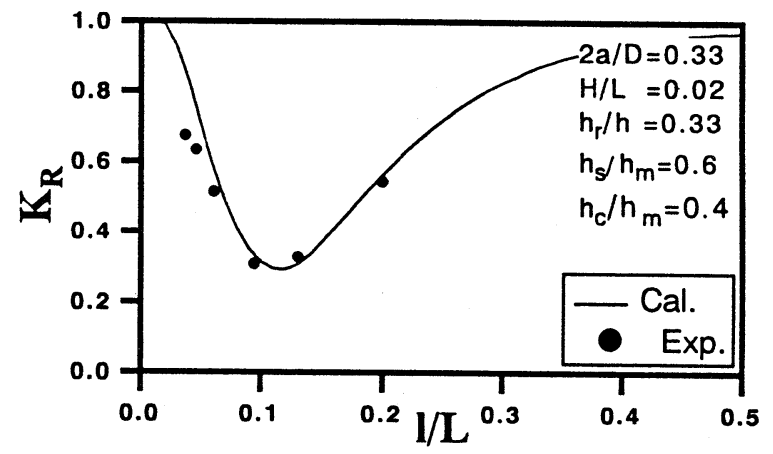

(b) Type 7

図-7 理論値と実験値との比較

\section{3 ）複合断面の検討}

以上の検討によって, マウンド上に設置されたステップスリットケーソンの反射特性はマウンドがない場合の それとあまり変わらないが, マウンドの高さの変化は反射率に大きく影響をすること, また, マウンドを考虑し た理論値は実験値をよく表現することが分かった，そこで，以下では理論値を用いてマウンド上に設置されたス テップスリットケーソンの各要素が反射率に及ぼす影響について検討し, 消波勃果の高い諸元について検討する. 消波効果の判断は従来と同様に” 短周期側では従来の直立消波構造物とほぼ同じ反射率を示し, 長周期側では従 来型よりできるだけ小さな反射率となること”を基準として決める.

まず, 基本的な断面として張出部の高さを決める. 図一8は嵩上げ部がない状態で, 張出部の高さによる反射 率の変化を見たものである. ここで，張出部の厚さは前述したようにスリット壁の厚さの 3 倍とした. 図による と $\left(h_{s} / h_{m}\right)$ か高くなるほど反射率の值は小さくなる. また, 反射率 $\left(K_{R}\right)$ が最小値を示す相対遊水室幅 $(l / L)_{p}$ が長周 期側にずれて短周期側では反射率がわずかに悪くなる傾向がある. 表一 1 に, 反射率が 0.5 以下になる相対遊水 室幅 $(l / L)$ の領域を示したが, 上述の判断基準によると張出部の最適高さは $\left(h_{s} / h_{m}\right)=0.6$ となる. 図一 9 は $\left(h_{s} / h_{m}\right)=0.6$ として, 遊水室内の嵩上け部の高さによる反射率の変化を見たものである. 図によると張出部と同 じ傾向を示していて, 前述した判断基準を使うと, 表一 2 より嵩上け部の最適高さは $\left(h_{c} / h_{m}\right)=0.4$ となる. 以上 より, ステップスリットケーソンの最適断面として, 張出部の高さは $\left(h_{s} / h_{m}\right)=0.6$, 嵩上げ部の高さは $\left(h_{c} / h_{m}\right)=0.4$ の組み合わせがよいことになる. ここで, さらに複合断面での張出部の影響を検討して見る. 図一 10 は嵩上け部の高さを $\left(h_{c} / h_{m}\right)=0.4$ とて, 張出部を設けた場合と設けない場合とを比較した図である. また表一 3 にはその状態での反射率が 0.5 以下になる相対遊水室幅 $(l / L)$ の領域と反射率の最小値を示す. これらによると 張出部を設けた場合の方が広い周期帯で低い反射率を示すことが分かる.

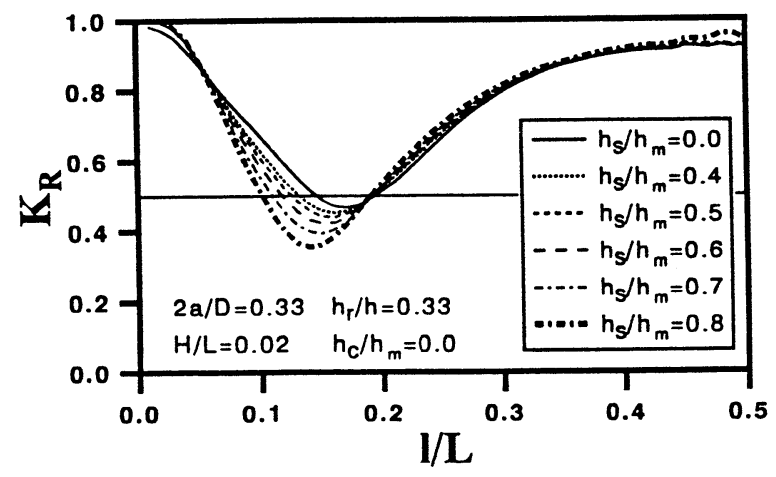

\begin{tabular}{|c|c|}
\hline \multicolumn{2}{|r|}{ 表一 1} \\
\hline$h_{s} / h_{m}$ & $K_{s}$ が 0.5 以下になる $/ / L$ の領域 \\
\hline 0.0 & $0.15 \sim 0.19$ \\
\hline 0.4 & $0.14 \sim 0.19$ \\
\hline 0.5 & $0.13 \sim 0.19$ \\
\hline 0.6 & $0.12 \sim 0.19$ \\
\hline 0.7 & $0.11 \sim 0.18$ \\
\hline 0.8 & $0.11 \sim 0.18$ \\
\hline
\end{tabular}

図-8＼cjkstart張出部高さによる反射率の変化 


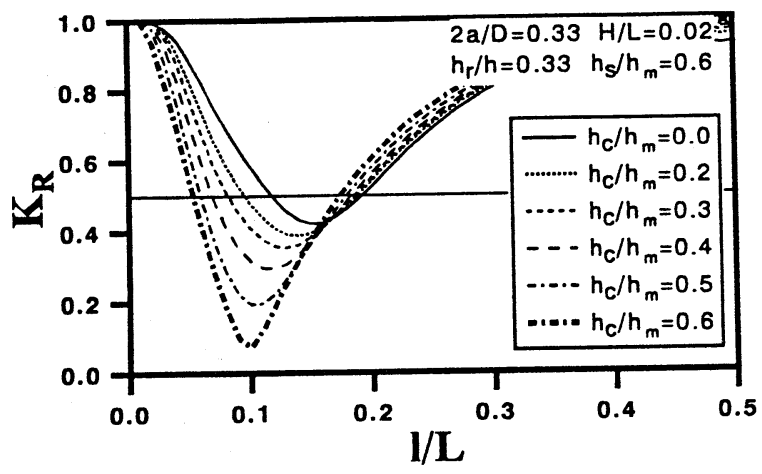

図ー9＼cjkstart嵩上げ部高さによる反射率の変化

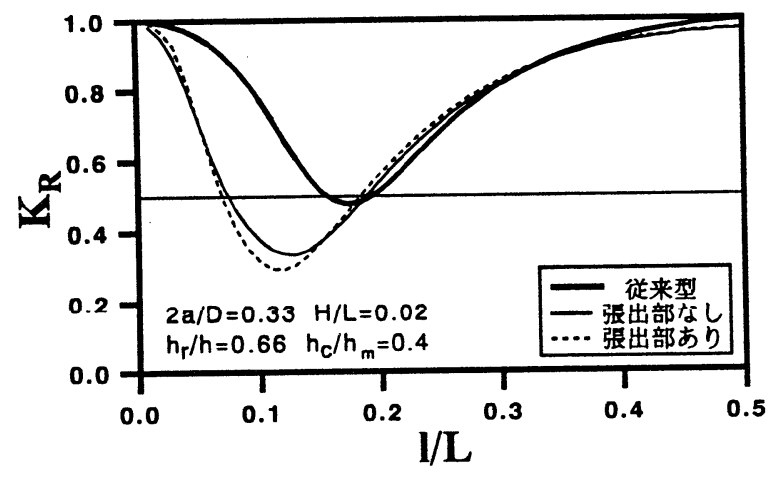

図一 10 張出部の影響
表一 2

\begin{tabular}{|l|l|}
\hline$h_{c} / h_{m}$ & $K_{s}$ が 0.5 以下になる $/ L$ の領域 \\
\hline 0.0 & $0.12 \sim 0.19$ \\
\hline 0.2 & $0.10 \sim 0.18$ \\
\hline 0.3 & $0.09 \sim 0.18$ \\
\hline 0.4 & $0.07 \sim 0.18$ \\
\hline 0.5 & $0.06 \sim 0.17$ \\
\hline 0.6 & $0.06 \sim 0.17$ \\
\hline
\end{tabular}

表-3

\begin{tabular}{|l|c|c|}
\hline & $K_{s}$ が0.5 以下になる $/ L$ の領域 & 最小値 \\
\hline 従来型 & $0.16 \sim 0.19$ & 0.477 \\
\hline 張出部なし & $0.08 \sim 0.18$ & 0.33 \\
\hline 張出部あり & $0.07 \sim 0.18$ & 0.29 \\
\hline
\end{tabular}

\section{5.まとめ}

以上, マウンド上に設置されたステップスリットケーソンの反射率の特性を実験によって調へるとともに, 新 たにマウンドの効果も考慮に入れることのできる数值計算手法を開発した. 結果を要約すると以下のようになる.

（1）反射率の計算結果は実験結果とよく一致し，本手法の妥当性とともに精度のよさも確認できた.

(2) 張出部および嵩上げ部ともに反射率の低滅に効果があり, 両者の効果によってかなり広い周波数帯域にわ たって低反射機能を実現できる.

(3) ステップスリットケーソンの最適断面は張出部の高さは $\left(h_{s} / h_{m}\right)=0.6$, 嵩上げ部の高さは $\left(h_{c} / h_{m}\right)=0.4 の$ 組 み合わせになる.

(4) 張出部を設けることによって, 短周期側での低反射性能を保持しつつ, 長周期側でのより低い反射性能を得 ることかできる.

今後は, 波力特性および越波特性についての検討を行い,これらを合わせた現地の適用性を明かにするつもりで ある.

\section{参考文献}

1) 合田良実・鈴木康正・岸良安治・菊地 治 : 不規則波実験における入・反射波の分離推定法，港湾技研資料， No.248, 28 p. , 1976.

2) 角野昇八・小田一紀・重松孝昌・芳田利春 : 広周波数帯域にわたって低反射機能を有する直立消波工の 開発, 第 35 回海岸工学論文集, PP. 557-561, 1988.

3) 角野昇八・小田一紀・藤田 孝・寺岡章吾・芳田利春 : スリットと任意断面で構成される構造物の消波 特性の解析, 第 36 回海岸工学論文集, PP. 499-503, 1989.

4 ) R.Fujiwara.,T.Yoshida.,K.Kurata.,S.Kakuno., and K.Oda (1994) : A new type of Breakwater with a StepShaped slit wall, Int. Conf. on Hydro-Technical Engrg. for Port and Harbor Const., pp.543-562. 